\title{
Maistuuko tattaripuuro?
}

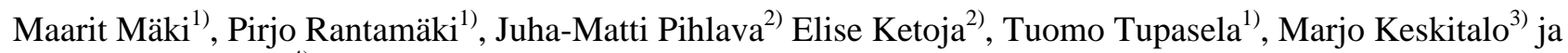
Anja Lapveteläinen ${ }^{4)}$

${ }^{1)}$ MTT Biotekniikka- ja elintarviketutkimus, 31600 Jokioinen, etunimi.sukunimi@mtt.fi

${ }^{2)}$ MTT Palveluyksikkö, 31600 Jokioinen, elise.ketoja@mtt.fi

${ }^{3)}$ MTT Kasvintuotannon tutkimus, 31600 Jokioinen, marjo.keskitalo@mtt.fi

${ }^{4)}$ Kuopion yliopisto, Kliinisen ravitsemustieteen yksikkö, ETTK, PL 1627, 70211 Kuopio, anja.lapvetelainen@uku.fi

\section{Tiivistelmä}

Tattari (Fagopyrum esculentum) on perinteinen suomalainen viljelyskasvi. Uudet tutkimusmenetelmät ovat tuoneet esiin sen monia terveyteen edullisesti vaikuttavia ominaisuuksia. Tattari on hyvä antioksidanttien lähde ja eläinkokeiden perusteella sen katsotaan alentavan veren kolesterolia. Se saattaa myös olla hyödyksi tyypin 2 diabeteksen hoidossa sisältämänsä D-chiro-inositolin takia. Tattari ei sisällä gluteenia, joten keliakiaa sairastavat voivat myös käyttää tattarituotteita. Tattarin voimakas maku kuitenkin jakaa kuluttajien mielipiteitä. Tässä tutkimuksessa pyrittiin erittelemään tattarin aistinvaraisia ominaisuuksia ja selvittämään, kuinka paljon tattarilajikkeet eroavat aistinvaraisesti toisistaan.

Tutkimuksessa luotiin tattarille aistinvarainen profiili, jota sovellettiin hankkeessa viljeltyihin tattarilajikkeisiin. Profiili rakennettiin MTT:n aistinvaraisessa laboratoriossa yhdessä Kuopion yliopiston kanssa. Tutkimusta varten koulutettiin 10 henkilön asiantuntijaraati. Arvioitavaksi tuotteeksi valittiin tattaripuuro, joka sisälsi vain tattaria ja vettä. Puuro valittiin, koska se on perinteinen suomalainen tattariruoka eikä sisällä tulokseen mahdollisesti vaikuttavia ulkopuolisia ainesosia. Tattaripuurosta määritettiin tyypillisimmät aistinvaraiset ominaisuudet hajun, maun, rakenteen ja ulkonäön suhteen. Puuroon käytetyistä tattarirouheista analysoitiin myös kemiallinen peruskoostumus.

Tattarista määritettiin ja nimettiin kaksi hajua (perunamainen ja viljainen/rukiinen haju), kolme makua (karvaus, maun yleisvoimakkuus ja tattarin maku), kaksi rakenneominaisuutta (ryynimäisyys ja leseisyys) ja kaksi ulkonäköön liittyvää ominaisuutta (kirjavuus ja tummuus). Erityisesti tattarin ominaismaun määrittely osoittautui vaativaksi tehtäväksi. Ensimmäisessä vaiheessa muodostettiin profiili eräille kaupallisille tattarituotteille. Menetelmän kehittämisen jälkeen tehtiin kaksi lajikkeiden välistä vertailua. Ensimmäisessä kokeessa verrattiin kuutta ja toisessa kokeessa neljää MTT:ssä viljeltyä lajiketta. Lajikkeet olivat peräisin Latviasta, Puolasta ja Suomesta.

Tutkimuksessa luotiin kullekin mukana olleelle lajikkeelle oma aistinvarainen profiili valittujen yhdeksän ominaisuuden voimakkuusarviointien perusteella. Tilastollisesti merkitseviä eroja tattaripuurojen välillä havaittiin kuitenkin ainoastaan puuron kirjavuudessa ja värin tummuudessa. Tulokset viittaavat siihen, että nämä Suomen viljelyoloissa satoa tuottavat lajikkeet voi aistinvaraisesti erottaa toisistaan lähinnä niistä tuotetun elintarvikkeen ulkonäön suhteen.

Tässä MMM:n rahoittamassa Terveyttä tattarista -hankkeessa tutkittiin tattarin aistinvaraisten ominaisuuksien ohella eri lajikkeiden satoisuutta, pölyttävien hyönteisten osuutta pähkylöiden muodostukseen, tattarin pähkylöiden kemiallista koostumusta, prosessoitavuutta ja eri jakeiden antioksidanttiaktiivisuutta.

Asiasanat: tattari, aistinvarainen arviointi, keliakia, diabetes, kolesteroli 


\section{Johdanto}

Tattari on yksi vanhimmista viljan tavoin käytettävistä kasveista, mitä Suomessa on viljelty. Tällä hetkellä viljelyala on vajaat 500 hehtaaria. Tattarin viljelyn lisääntyminen olisi suotavaa, sillä tattarilla on tulevaisuutta terveellisten elintarvikkeiden raaka-aineena. Nykyään tattaria joudutaan tuomaan huomattava määrä ulkomailta kotimaisen tuotannon täydennykseksi. Kemialliset ja immunologiset tutkimukset ovat osoittaneet, että tattari soveltuu henkilöille, jotka eivät siedä viljan gluteenia. Tämä johtuu siitä, että tattarin proteiinista erittäin pieni osa on prolamiinia (Skerrit 1986). Tattari on myös hyvä antioksidanttien lähde (Gorinstein ym. 2007, Jiang ym. 2007) ja sen katsotaan alentavan veren kolesterolia (Tomotake ym. 2006, He ym. 1995). Se saattaa myös olla hyödyksi tyypin 2 diabeteksen hoidossa sisältämänsä D-chiro-inositolin takia (Ostlund ym. 1993, Ortmeyer ym. 1995). Tattarin maku kuitenkin jakaa kuluttajien mielipiteitä. Tattarilla on oma vankka kannattajajoukkonsa, joka pitää tattarin mausta ja tietoisesti hakee voimakasta ja karvastakin makua, kun taas osa kuluttajista taas suosii miedomman makuisia viljatuotteita. Tattarista valmistettuja elintarvikkeita käytetään eniten Aasiassa, mutta myös Euroopassa on vahva tattariruokakulttuuri.

Tattarin makua pidetään usein voimakkaana. Terveyttä edistävät, flavonoideihin kuuluvat yhdisteet, mm. kversetiini ja rutiini tuovat makuun karvautta. Tattarille ominaista aromia on jäljitetty mm. kaasukromatografi-massaspektrometriin yhdistetyllä hajuanalyysillä. Ilmeisesti tattarin aromi syntyy monien komponenttien yhteisvaikutuksena. Vaikuttavina aineosina on mainittu oktenoli, tiatsolit ja etyylikinnamaatti (Yajima ym. 1983, Mazza ym. 1999, Sakaida ym. 2003). Tutkimustuloksia siitä, miten eri tattarilajikkeiden aistinvaraiset ominaisuudet poikkeavat toisistaan, ei ole tietojemme mukaan julkaistu. Satoisuuden, kestävyyden ja muiden viljelyominaisuuksien ohella lajikkeiden valinnassa on tärkeää ottaa huomioon aistinvarainen laatu.

Tämän tutkimuksen tavoitteena oli luoda kvantitatiivinen kuvaileva arviointimenetelmä, jonka avulla voidaan arvioida esim. erilaisten tattarilajikkeitten eroja aistittavan laadun suhteen.

\section{Aineisto ja menetelmät}

Tutkimus toteutettiin luomalla ensin aistinvarainen profiili, jota sovellettiin hankkeessa viljeltyihin tattarilajikkeisiin. Profiili rakennettiin MTT:n aistinvaraisessa laboratoriossa yhdessä Kuopion yliopiston kanssa. Tutkimusta varten koulutettiin 10 henkilön asiantuntijaraati. Arvioitavaksi tuotteeksi valittiin tattaripuuro, joka sisälsi vain tattaria ja vettä. Puuro valittiin, koska se on perinteinen suomalainen tattariruoka eikä sisällä tulokseen mahdollisesti vaikuttavia ulkopuolisia ainesosia.

Tattaripuurosta määritettiin tyypillisimmät aistinvaraiset ominaisuudet hajun, maun rakenteen ja ulkonäön suhteen. Sanaston, referenssien ja asteikon määrittäminen tapahtui yhteisissä arviointi- ja keskustelutilaisuuksissa, jonka jälkeen arvioijat tekivät itsenäisen harjoitusarvioinnin. Asteikkona käytettiin $10 \mathrm{~cm}$ jana-asteikkoa. Värin voimakkuus arvioitiin erikseen numeerisella asteikolla (1-10). Taulukossa 1. on esitetty puurosta arvioidut aistittavat ominaisuudet ja niiden vertailunäytteet.

Taulukko 1. Tattaripuuron kvantitatiivisesti arvioidut aistittavat ominaisuudet ja niiden vertailunäytteet.

\begin{tabular}{|c|c|c|}
\hline \multicolumn{2}{|l|}{ Ominaisuus } & Vertailunäyte/materiaali \\
\hline \multirow[t]{2}{*}{ HAJU } & 1. Perunamainen & Uunissa kypsennetty peruna hajupullossa \\
\hline & 2. Rukiinen/viljainen & Ruispuuro, joka oli valmistettu ruisjauhosta ja vedestä. \\
\hline \multirow[t]{3}{*}{ MAKU } & 3. Karvaus, kitkeryys & Haudutettu pussitee (1 teepussi/1 l vettä, 30 min). \\
\hline & $\begin{array}{l}\text { 4. Maun kokonais- } \\
\text { voimakkuus }\end{array}$ & Ei vertailunäytettä \\
\hline & 5. Tattarin maku & $\begin{array}{l}\text { Ei vertailunäytettä. Arvioijille annettu kaksi puuronäytettä, joista } \\
\text { toisessa oli tyypillinen ja toisessa voimakas, mutta epätyypillinen } \\
\text { tattarin maku. }\end{array}$ \\
\hline \multirow[t]{2}{*}{ SUUTUNTUMA } & 6. Ryynimäisyys & Ohrapuuro, joka oli valmistettu rikotuista ohraryyneistä \\
\hline & 7. Leseisyys & $\begin{array}{l}\text { Arvioitu asteikolla, jonka ääripää rouheinen, erottuvia leseitä (10): } 60 \text { g } \\
\text { vellijauhetta, } 50 \text { g pikakaurahiutaletta, vettä } 1 \text { litra, keittoaika } 1 \text { min, } \\
\text { jonka jälkeen lisätään: } 15 \text { g vehnäleseitä ja } 30 \text { g seesaminsiemeniä. }\end{array}$ \\
\hline \multirow[t]{2}{*}{ ULKONÄKÖ } & 8. Kirjavuus & $\begin{array}{l}\text { Ei vertailunäytettä. Arvioijat ohjeistettu: kirjavassa näytteessä } \\
\text { puuromassassa erottuu useanlaisia, mahdollisesti erivärisiäkin } \\
\text { partikkeleita. }\end{array}$ \\
\hline & 9. Värin tummuus & $\begin{array}{l}\text { Arvioitu muista ominaisuuksista poiketen numeerisella asteikolla 1-10 } \\
2 \text { = NCS värimalli S3010-Y90R ja 9= S2005-Y90R. }\end{array}$ \\
\hline
\end{tabular}


Puurot valmistettiin lisäämällä 130 g tattarirouhetta ja 11 lähdevettä ja rouheiden paino vakioitiin 13 \% kosteuden mukaan. Puurot valmistettiin uunissa hauduttamalla kannellisessa astiassa $175{ }^{\circ} \mathrm{C}$ :ssa $1,5 \mathrm{~h}$. Puuroja pidettiin 10 - 15 min huoneenlämmössä tasapainottumassa, jonka jälkeen ne annosteltiin $30 \mathrm{ml}$ lasikuppeihin, jotka oli peitetty lasikannella. Näytteet pidettiin lämpiminä arviointihetkeen saakka. Näytteet arvioitiin kolminumeroisilla tunnuksilla koodattuina. Näytteiden välillä arvioijat huuhtoivat suun vedellä ja söivät palan tuorekurkkua suun neutraloimiseksi.

Aistinvaraisen profiilin toimivuus testattiin kaupallisilla tattarituotteilla (Koe 1). Tutkitut näytteet olivat 1) Ilkka Säde, rikottu tattarisuurimo, 2) Keskisen myllyn tattarirouhe, karkea jauhatus, 3) sama Keskisen myllyn rouhe, joka uudelleen jauhettiin MTT:llä sekä 4) Myllyn paras kokonainen tattarisuurimo. Arvioinnit tehtiin kahdessa osassa, neljä arviointikertaa syyskuussa 2004 ja kolme tammikuussa 2005. Kokeessa tutkittiin myös jauhatusasteen vaikutusta arviointituloksiin. Puuroon käytetyistä tattarirouheista analysoitiin myös kemiallinen peruskoostumus.

MTT:ssä tehdyissä lajikekokeissa tuotettujen tattarisuurimoiden aistittavia ominaisuuksia kuvattiin kolmen kokeen sarjassa noin puoli vuotta sadonkorjuun jälkeen marras-joulukuussa 2005 ja tammikuussa 2006 (Kokeet 2a-2c), ja lisäksi yhdessä kokeessa vuosi sadonkorjuun jälkeen elokuussa 2006 (Koe 3). Tattarilajikkeita oli kasvatettu neljällä eri peltolohkolla, jotka arvosteltiin eri arviointikerroilla. Tattarit varastoitiin kuivassa varastossa n. 13 asteessa. Tattarisuurimoista tutkittiin maaliskuussa 2006 hiiva- ja homemäärät YGC-agarilla (Difco, inkubointi 5 vrk 25 asteessa). Kokeissa 2a-2c MTT:ssä tuotettujen lajikkeiden lisäksi arvioinneissa oli mukana kontrollina kaupan suurimoita (Ilkka Säde, rikottu suurimo ja Myllyn Paras, kokonainen suurimo). Tutkitut lajikkeet olivat Aiva (Latvia), Ilkka (Suomi), Keskinen (Suomi), Kora (Puola), Luba (Puola) ja Panda (Puola). Arviointikertoja oli yhteensä 12 ja niissä jokainen arvioija arvioi kaksi kontrollinäytettä ja kaksi lajikenäytettä. Näytteiden arviointijärjestys satunnaistettiin jokaisen arvioijan kohdalla erikseen. Arvioijille järjestettiin ennen arviointeja itsenäisesti suoritettu harjoitusarviointi. Kokeessa 3 arvioinnit toistettiin ilman kontrolleja. Tutkitut lajikkeet olivat Ilkka, Keskinen, Kora ja Panda. Arvioijia oli kokeessa kahdeksan. Arvioijat satunnaistettiin neljän lajikkeen näytesarjoihin Williamsin latinalaisia 4x4-neliöitä käyttäen (Williams 1949). Aineistot analysoitiin yleisiä lineaarisia sekamalleja käyttäen.

\section{Tulokset ja tulosten tarkastelu}

Kokeessa 1 tutkitut tattarituotteet erosivat selvimmin ulkonäön ja suutuntuman perusteella. Ilkka Säde oli väriltään tummin, kirjavin ja maultaan voimakkain. Jauhaminen tummensi tattarirouheen väriä ja lisäsi kirjavuutta (Keskinen, MTT rouhe). Tammikuun arvioinnissa näytteiden väliset erot arvioitiin jonkin verran pienemmiksi kuin syyskuussa. Kokeessa käytetty Ilkka Säde poikkesi muista näytteistä sekä aistittavilta ominaisuuksiltaan että koostumukseltaan (Taulukko 2). Erityisesti rutiini- ja kversetiinipitoisuudet olivat korkeampia. Muissa tutkimuksessa on saatu Fagopyrum esculentum-lajin kuorituille siemenille rutiinipitoisuudeksi 0,02 \% (Jiang ym. 2007) ja 0,01 \% kuiva-aineessa (Fabjan ym. 2003), joka on samaa tasoa kuin tässä tutkimuksessa saadut analyysitulokset.

Taulukko 2. Aistinvaraisessa arvioinnissa tutkittujen tattarisuurimoiden peruskoostumus sekä rutiini ja kversetiinipitoisuudet (Koe 1).

\begin{tabular}{|l|c|c|c|c|}
\hline & 1) Ilkka Säde & $\begin{array}{l}\text { 2) Keskinen, } \\
\text { kaupan tuote }\end{array}$ & $\begin{array}{l}\text { 3) Keskinen, } \\
\text { MTT rouhe }\end{array}$ & $\begin{array}{c}\text { 4) Myllyn paras kokon. } \\
\text { tattarisuurimo }\end{array}$ \\
\hline Energia kJ/100 g & 1594 & 1558 & 1571 & 1574 \\
\hline Proteiini g/100 g tp & 18,8 & 10,4 & 12,9 & 14,6 \\
\hline Hiilihydr. g/100 g tp & 64,8 & 76,4 & 72,9 & 70,7 \\
\hline Raaka-rasva g/100 g tp & 4,67 & 2,22 & 3,03 & 3,35 \\
\hline Kosteus g/100 g & 8,78 & 9,28 & 9,06 & 9,45 \\
\hline Tuhka g/100 g tp & 2,95 & 1,68 & 2,13 & 1,94 \\
\hline Kokonais-ravintokuitu \% tp & 5,67 & $<2,8$ & 3,21 & 3,21 \\
\hline Tärkkelys \%tp & 58,6 & 72,7 & 68,3 & 66,1 \\
\hline Rutiini mg/100 g tp & 17,60 & 8,35 & 13,00 & 9,50 \\
\hline Kversetiini mg/100 g tp & 8,80 & 4,20 & 6,50 & 4,80 \\
\hline
\end{tabular}


Erot kokeen 2a tattarilajikkeiden välillä olivat hyvin pieniä (Taulukko 3). Toisaalta kontrollit erosivat tilastollisesti MTT:llä kasvatetuista lajikkeista ja toisistaan usean ominaisuuden suhteen. Myllyn paras -tattarituote koostui kokonaisista suurimoista, ja sen erottuminen muista ryynimäisyyden suhteen oli ilmeinen. Vaikeimmin arvioitavaksi ominaisuudeksi osoittautui perunamainen haju, jossa eroja saatiin esiin vähän. Lajikkeiden välillä todettiin tilastollisesti merkitseviä eroja ainoastaan puurojen värin suhteen. Ilkka oli tummempi kuin Keskinen $(\mathrm{P}<0,01)$ ja Aiva oli tummempi kuin Kora $(\mathrm{P}<0,001)$. Kokeen 2 MTT:llä kasvatettujen tattarilajikkeiden hiiva- ja homemäärät olivat melko korkeat verrattuna kaupan suurimoihin (Taulukko 4). Tämä saattaa johtua korjuuhetken lämpimistä ja kosteista olosuhteista.

Taulukko 3. Arvioitujen ominaisuuksien keskimääräiset voimakkuudet kokeissa 2a-2c. Keskiarvojen keskivirheet vaihtelivat välillä 0,3-0,6.

\begin{tabular}{|c|c|c|c|c|c|c|c|c|c|}
\hline & \multicolumn{2}{|l|}{ Haju } & \multicolumn{2}{|c|}{ Ulkonäkö } & \multicolumn{3}{|l|}{ Maku } & \multicolumn{2}{|c|}{ Suutuntuma } \\
\hline Näyte & $\begin{array}{l}\text { Peruna- } \\
\text { mainen }\end{array}$ & $\begin{array}{l}\text { Rukii- } \\
\text { nen }\end{array}$ & $\begin{array}{l}\text { Kirja- } \\
\text { vuus }\end{array}$ & $\begin{array}{l}\text { Värin } \\
\text { tummuus }\end{array}$ & Karvaus & $\begin{array}{l}\text { Kokonais- } \\
\text { voimakkuus }\end{array}$ & $\begin{array}{l}\text { Tattarin } \\
\text { maku }\end{array}$ & $\begin{array}{l}\text { Ryyni- } \\
\text { mäisyys }\end{array}$ & $\begin{array}{l}\text { Lesei- } \\
\text { syys }\end{array}$ \\
\hline AIVA & 3,8 & 4,3 & 5,6 & 7,7 & 3,5 & 5,3 & 5,5 & 5,6 & 4,5 \\
\hline KORA & 4,0 & 4,1 & 5,6 & 5,9 & 3,8 & 4,9 & 5,0 & 5,4 & 4,2 \\
\hline LUBA & 3,8 & 4,0 & 5,5 & 6,8 & 3,7 & 4,9 & 5,1 & 5,6 & 3,7 \\
\hline PANDA & 3,6 & 3,9 & 5,5 & 6,9 & 4,1 & 5,2 & 5,0 & 5,9 & 3,6 \\
\hline ILKKA & 3,6 & 4,7 & 6,5 & 7,8 & 4,5 & 5,4 & 5,1 & 5,3 & 5,2 \\
\hline KESKINEN & 3,9 & 4,0 & 5,7 & 6,5 & 4,3 & 5,4 & 4,9 & 5,1 & 4,8 \\
\hline $\begin{array}{l}\text { Myllyn } \\
\text { Paras }\end{array}$ & 3,7 & 4,0 & 5,4 & 4,7 & 3,9 & 4,8 & 5,3 & 6,9 & 4,0 \\
\hline Ilkka Säde & 3,7 & 3,0 & 2,7 & 1,7 & 3,2 & 3,6 & 4,0 & 2,2 & 2,1 \\
\hline
\end{tabular}

Taulukko 4. Tattarisuurimoiden hiiva- ja homemäärät (Kokeet 2a-2c).

\begin{tabular}{|l|c|c|}
\hline Näyte & Hiivat & Homeet \\
\hline & $\begin{array}{l}\text { Keskiarvo } \\
\lg (\text { pmy/g) }\end{array}$ & $\begin{array}{c}\text { Keskiarvo } \\
\lg (\text { pmy/g) }\end{array}$ \\
\hline AIVA & 5,96 & $<4$ \\
\hline KORA & 5,94 & $<4$ \\
\hline LUBA & 5,50 & $<4$ \\
\hline PANDA & 5,67 & $<4$ \\
\hline ILKKA & 6,26 & 4,13 \\
\hline KESKINEN & 5,93 & 4,00 \\
\hline Myllyn Paras & $<3$ & $<3$ \\
\hline Ilkka Säde & $<3$ & 2,83 \\
\hline
\end{tabular}

Kokeen 3 tulosten perusteella todettiin tilastollisesti merkitseviä eroja lajikkeiden välillä ainoastaan puuron ulkonäön kirjavuuden ja värin tummuuden suhteen (Kuva 1). Ilkka oli väriltään tummin (keskiarvo $7,2)$ ja kirjavin $(6,4)$ ja Keskinen toiseksi tummin $(5,7)$ ja kirjavin $(5,8)$. Kora ja Panda on arvioitu hyvin samanlaisiksi näiden ominaisuuksien suhteen ja ne eroavat Ilkasta tilastollisesti merkitsevästi mutta eivät Keskisestä. 


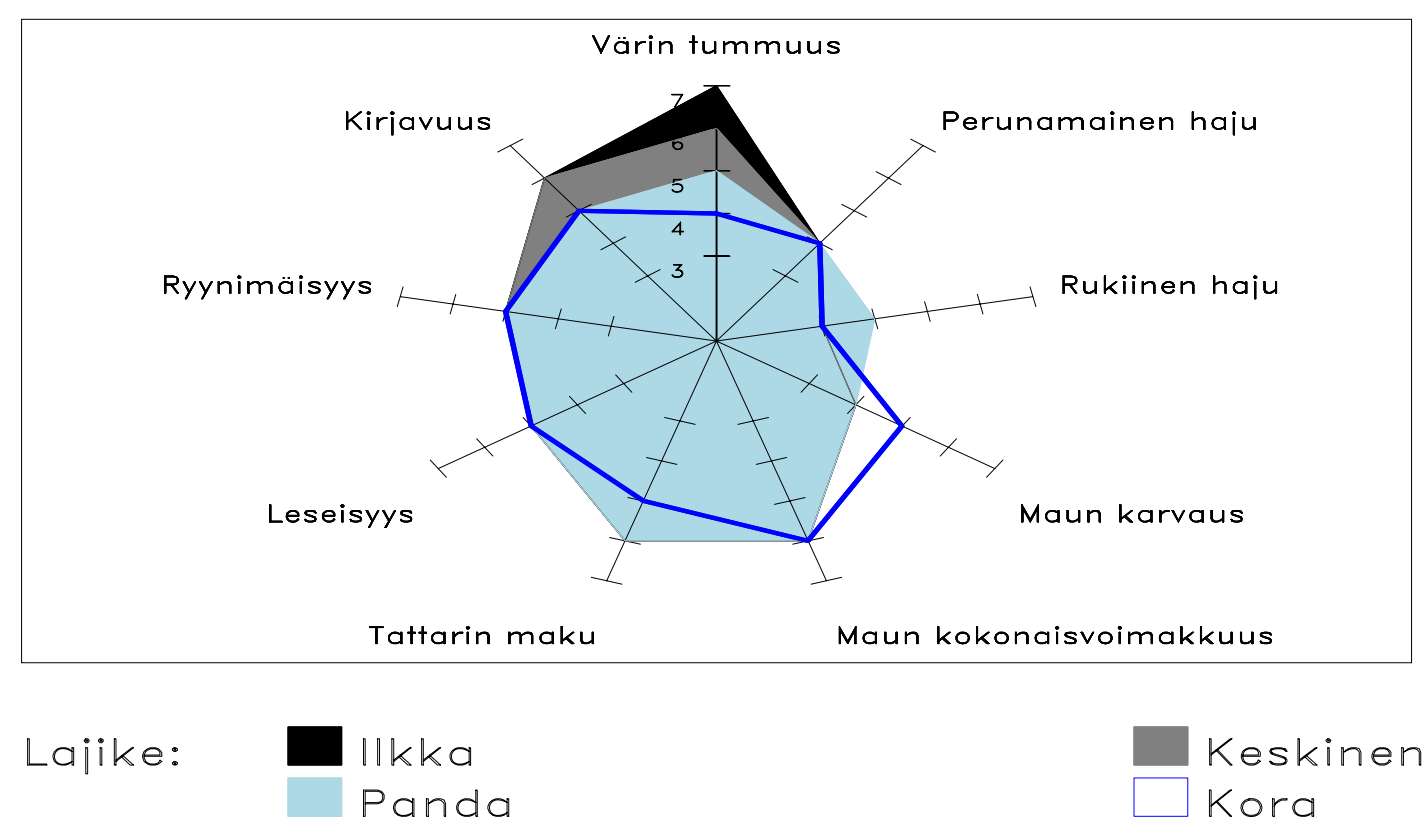

Kuva 1. Tähtikuvio neljästä eri tattarilajikkeesta valmistetun puuron ominaisuuksien keskimääräisistä voimakkuuksista. (Koe 3).

\section{Johtopäätökset}

Tulokset viittaavat siihen, että tutkitut Suomen viljelyoloissa satoa tuottavat lajikkeet voi aistinvaraisesti erottaa toisistaan lähinnä niistä tuotetun elintarvikkeen ulkonäön suhteen. Mikrobiologiset tulokset painottavat korjuuolosuhteiden merkitystä ja tarvetta korjuun jälkeisen käsittelyn tutkimukseen ja kehitykseen. Tutkimuksessa saatiin kuvattua tattarilajikkeiden aistittavia ominaisuuksia, mutta kuluttajien suhtautumisesta tattarin aistittaviin ominaisuuksiin tarvitaan lisää tietoa.

\section{Kiitokset}

Kiitämme kaikkia arviointiraadin jäseniä sekä Seija Tuomarmäkeä ja Paula Laaksosta aistinvaraisten arviointien järjestämisestä sekä Anneli Paloposkea mikrobiologisista analyyseistä.

\section{Kirjallisuus}

Fabjan, N., Rode, J., Kosir, I. J., Zhuanhua, W., Zheng, Z. \& Kreft, I. 2003. Tartary buckwheat (Fagopyrum tataricum Gaertn.) as a source of dietary rutin and quercitrin. J. Agric. Food Chem. 51: 6452-6455.

Gorinstein, S., Toledo, F., Arancibia-Avila, P., Trakhtenberg, S., Katrich, E., Jaramillo, N.O., Vargas, O.J.M., Ayala, A.L.M. \& Salas, I.A. 2007. The total polyphenols and the antioxidant potentials of some selected cereals and pseudocereals. Zeitschrift für Lebensmittel-Untersuchung und -Forschung. A, European food research and technology 225: 321-328.

He, J., Klag, M.J., Whelton, P.K., Mo, J-P., Chen, J-Y., Qian, M-C, Mo, P-S \& He, G-Q. 1995. Oats and buckwheat intakes and cardiovascular disease risk factors in an ethnic minority of China. Am. J. Clin. Nutr. 61: 366372 .

Jiang, P., Burczynski, F., Campbell, C., Pierce, G., Austria, J. A. \& Briggs, C. J. 2007. Rutin and flavonoid contents in three buckwheat species Fagopyrum esculentum, F. tataricum, and F. homotropicum and their protective effects against lipid peroxidation. Food Res. Int. 40: 356-364.

Mazza, G., Cottrell, T., Malcolmson, L., Girard, B., Oomah, B.D. \& Eskins, M.A.M. 1999. Headspace gas chromatography and sensory analyses of buckwheat stored under controlled atmosphere. J. Food Qual. 22: $341-352$.

Ortmeyer, H.K., Larner, J. \& Hansen, B.C. 1995. Effects of $D$-chiro-inositol added to a meal on plasma glucose and insulin in hyperinsulinemic rhesus monkeys. Obes. Res. 3: 605-608.

Ostlund Jr, R.E., McGill, J.B., Herskowitz, I., Kipnis, D.M., Santiago, J.V. \& Sherman, W.R. 1993. D-chiroinositol metabolism in diabetes mellitus. Proc. Natl. Acad. Sci. 90: 9988-9992. 
Sakaida, H., Nakahara, N., Watashi, N., Kai, T., Nakashima, Y., Sakakibara, Y., Nishiyama, K., Fukuda, N. \& Suiko, M. 2003. Characteristic flavor of buckwheat Shochu and comparison of volatile compounds from variety cereal Shochu. J. Japanese Soc. Food Sci. Tech. 50: 555-562.

Skerrit, J.H. 1986. Molecular comparison of alcohol-soluble wheat and buckwheat proteins. Cereal Chem. 63: 29-34.

Tomotake, H., Yamamoto, N., Yanaka, N., Ohinata, H., Yamazaki, R., Kayashita, J. \& Kato, N. 2006. High protein buckwheat flour suppresses hypercholesterolemia in rats and gallstone formation in mice by hypercholesterolemic diet and body fat in rats because of its low protein digestibility. Nutrition 22: 166-173.

Williams, E.J. 1949. Experimental designs balanced for the estimation of residual effects of treatments. Austral. J. Sci. Res. 2: 149-168.

Yajima, I., Yanai, T., Nakamura, M., Sakakibara, H., Uchida, H. \& Hayashi, K. 1983. Volatile flavor compounds of boiled buckwheat flour. Agric. Biol. Chem. 47: 729-738. 